\title{
Chemoselective crossed acyloin condensations: catalyst and substrate control
}

Christopher A. Rose, ${ }^{a}$ Sivaji Gundala, ${ }^{b}$ and Stephen J. Connon, ${ }^{\text {b }}$ Kirsten Zeitler* ${ }^{\mathrm{a}}$

${ }^{a}$ Institut für Organische Chemie, Universität Regensburg, Universitätsstrasse 31, D-93053 Regensburg, Germany

${ }^{\mathrm{b}}$ Centre for Synthesis and Chemical Biology, School of Chemistry, The University of Dublin, Trinity College, Dublin 2, Ireland

Fax: ${ }^{\mathrm{a}}+499419434121^{\mathrm{b}}+35316712826$

E-mail: ${ }^{a}$ kirsten.zeitler@chemie.uni-regensburg.de ${ }^{\text {b }}$ connons@tcd.ie

Received: The date will be inserted once the manuscript is accepted.

Abstract: The interplay between catalyst and substrate control in crossed acyloin condensation reactions has been studied. It was found that a pentafluorophenyl-substituted triazolium ion derived catalyst was capable of catalyzing highly chemoselective processes between a range of aliphatic and aromatic aldehydes utilized in a 1:1 ratio.

Key words: organic synthesis, carbenes, heterocycles, catalysis, umpolung reactions.

The benzoin condensation (BC) is among the most well-known, time-honored transformations in organic chemistry. Discovered in $1832,{ }^{1}$ it is taught in most undergraduate courses around the world as an example of umpolung chemistry - two molecules of benzaldehyde react: one serves as an electrophile whereas the other behaves as a formal nucleophile in the presence of a catalyst. ${ }^{2}$

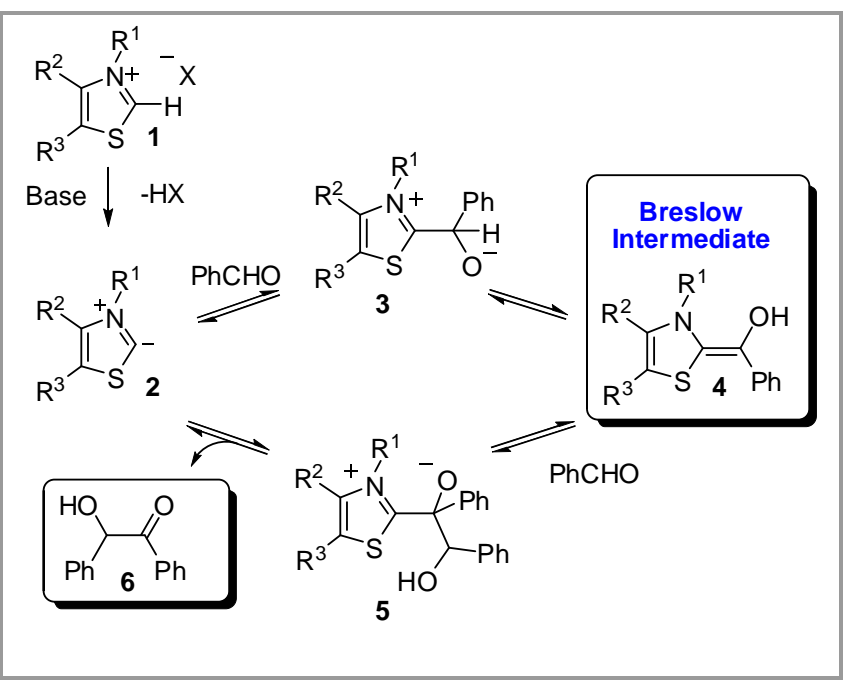

Figure 1 The mechanism of the thiazolium ion mediated benzoin condensation

The process was initially promoted by cyanide ion, however 70 years after its discovery a thiazolium ion mediated process (under basic conditions) was developed by Ugai et al. ${ }^{3}$ While studying thiamine dependent enzymes and their biological transformations the mechanism of the thiazolium ion mediated benzoin condensation was established in 1958 by Breslow ${ }^{4}$ as involving the intermediacy of the carbene 2 (Figure 1), formed from initial deprotonation of the thiazolium salt $\mathbf{1}$. This then adds to benzaldehyde to afford adduct 3 , which then undergoes proton transfer to yield the Breslow Intermediate (BI) 4. This nucleophilic species adds to a second molecule of benzaldehyde (for example) to afford 5, which eliminates benzoin (6) leading to the regeneration of carbene 2 , which is then available to re-enter the cycle and attack another benzaldehyde substrate molecule etc. ${ }^{5}$

In the 1990s, Enders pioneered the development of triazolium ion-derived carbene catalysts for the $\mathrm{BC}$ reaction. ${ }^{6}$ A distinct advantage associated with the use of these systems was their amenability to modification for the purposes of asymmetric catalysis - leading to impressive recent developments in the corresponding (enantioselective) homo-BC reaction. ${ }^{7,8}$

However, the standing of the $\mathrm{BC}$ as a useful synthetic methodology, especially as a intermolecular C-C coupling process, is not high among the synthetic community, due to an inherent chemoselectivity problem: while excellent product yields are possible in the homo-BC reaction, when the two reacting aldehyde moieties are not identical it is usual that no single $\alpha$-hydroxy ketone of the four possible products (Figure 2) dominates. This is perhaps not entirely surprising upon cursory analysis of the mechanism (Figure 1): if one of the aldehydes is more electrophilic than the other, it is likely to undergo nucleophilic attack faster in the steps to form both the $\mathrm{BI}($ i.e. $\mathbf{2} \rightarrow 3$ ) and the $\mathrm{C}-\mathrm{C}$ bond forming step (i.e. 4 $\rightarrow 5$ ). Therefore in the absence of any thermodynamic bias toward one product or the other, poor chemoselectivity would result.

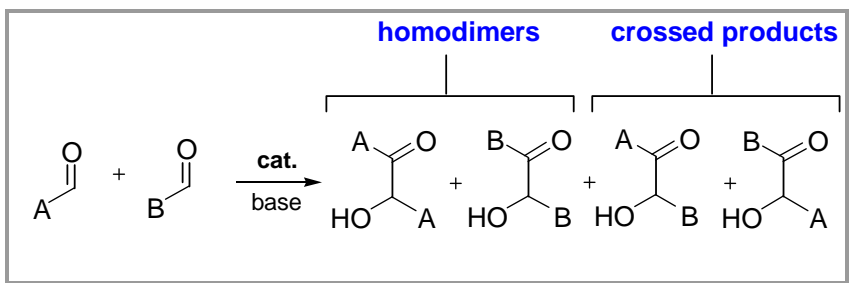

Figure 2 The four possible products from a crossed intermolecular $\mathrm{BC}$ reaction

The first attempts to find a solution to this chemoselectivity problem were made by Buck et al., ${ }^{9}$ who examined this influence of electronic effects in the cyanide ion catalyzed crossed $\mathrm{BC}$ of aromatic 
aldehydes - no general trends leading to chemoselective methodologies were uncovered. Later, Stetter and coworkers ${ }^{10}$ studied the thiazolium ion mediated reaction between aliphatic and aromatic aldehydes. When the aliphatic aldehyde was utilized in threefold excess good crossed product yields could be obtained. A curious finding was that chemoselectivity was highly substrate dependent: efficient, selective coupling was only observed in cases where the aromatic aldehyde either incorporated a $\pi$-excessive heterocycle or a chlorine atom in the ortho position. $^{11}$

While a number of intramolecular examples of crossed aldehyde-ketone benzoin reactions have been accomplished, ${ }^{12}$ more recently, Enders et al. demonstrated that 2,2,2-trifluoromethylacetophenone can serve as an electrophilic reaction partner in intermolecular crossed acyloin condensation (AC) reactions with electron rich heterocyclic aldehydes. $^{13,14,15}$ The choice of electrophile was crucial - the ketone is reactive enough to be attacked by the BI but is incapable of participating in BIformation as it is devoid of an aldehyde proton.

In general, an efficient, $N$-heterocyclic carbene (NHC)-catalyzed chemoselective intermolecular crossed AC methodology of broad scope remains outside the orbit of current technology, which has prompted the development of several useful either indirect $^{16}$ or enzyme-catalyzed ${ }^{17}$ methodologies for the synthesis of these products.

With the objective of developing upon a recent finding that ortho-substituted benzaldehydes could participate in chemoselective crossed acyloin reactions with aliphatic aldehydes ${ }^{17 \mathrm{c}}$ in the presence of triazolium salt-derived carbenes, ${ }^{18}$ we began to investigate the influence of both substrate- and catalyst structure on the chemoselective outcome of the crossed AC reaction - we were particularly interested in the performance differential between Stetter's thiazolium ion precatalyst $18^{10 \mathrm{a}}$ and a triazolium analogue 19 which we have recently found to serve as an excellent promoter of both $\mathrm{BC}^{8 \mathrm{f}}$ and crossed $\mathrm{AC}$ reactions. ${ }^{18}$

Since it appeared that single aspects of Stetter's findings (in particular the chemoselectivity associated with the use of $o$-chlorobenzaldehyde as a coupling partner) seemed at odds with our recent study, ${ }^{18}$ we decided to repeat selected examples from Stetter's original work (condition set A), and compare the results with those an analogous reaction involving triazolium ion 19 under conditions optimized for its use (condition set B). The results of these experiments are outlined in Table 1.

The reactions under investigation involved the coupling of benzaldehydes 7-11 with isobutyraldehyde (12) in either a 3:1 (condition set A 'Stetter') or a 1:1 ratio (condition set B) respectively. As Stetter had originally reported, benzaldehyde (7) participated in a broadly unselective process (save the expected absence of the hindered homo-AC product 13a) hitherto typical of these types of coupling reactions (entries 1-2). ${ }^{19}$ Using the triazolium ion precatalyst however (condition set B, entry 3) a considerably more selective process takes place: cross product 13d (via the intermediacy of a BI derived from initial attack of the catalyst on 12) is dominant, with small amounts of benzoin (13b) also formed.

Table 1 Crossed AC reactions under either Stetter's original conditions (reference and repeated) or under optimized conditions using a triazolium ion precatalyst

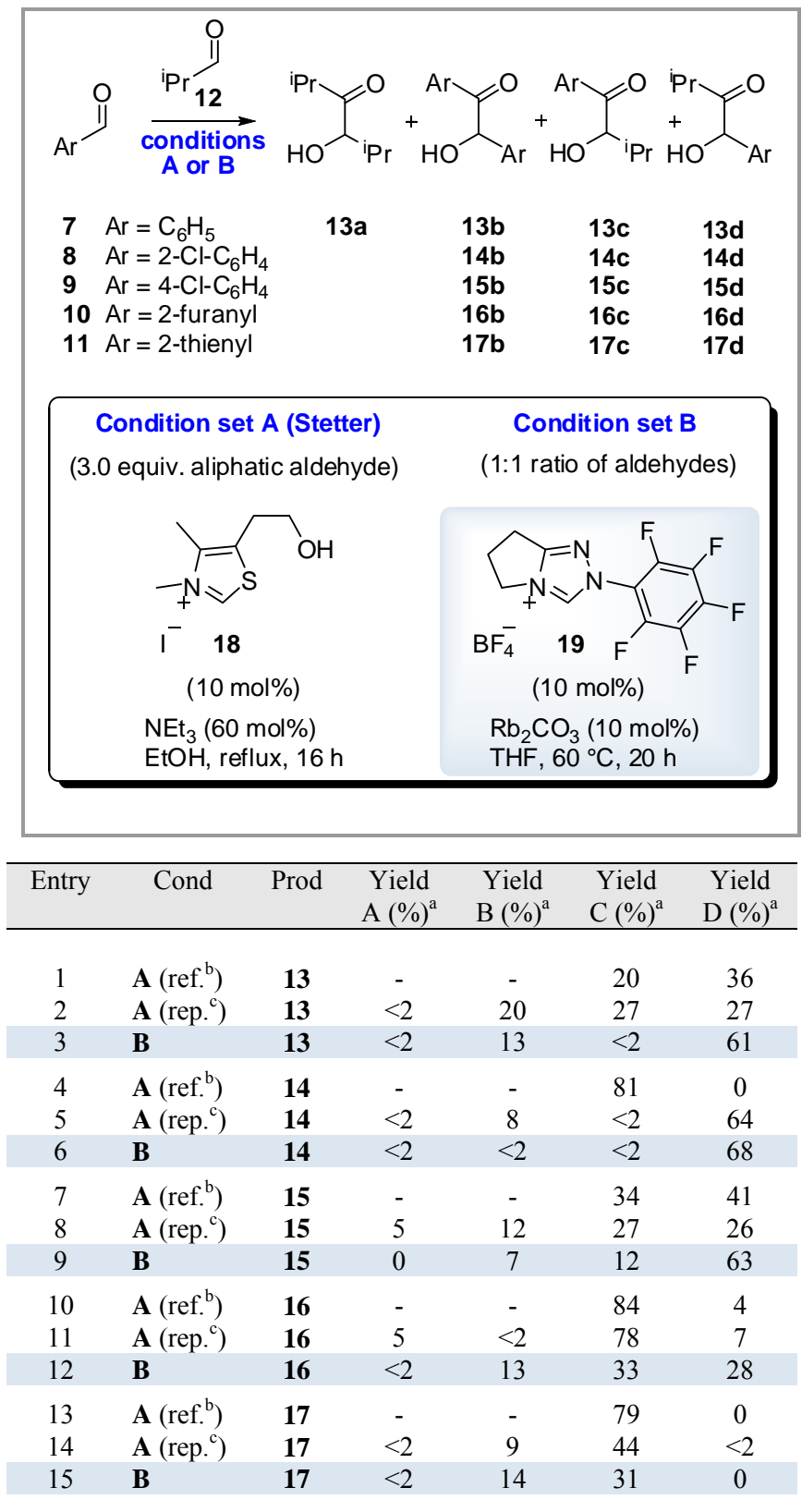

${ }^{\mathrm{a}}$ Yield determined by ${ }^{1} \mathrm{H}$ NMR spectroscopy using (E)-stilbene as an internal standard. Note: yields of 13-17a and 13-17b account for the 2:1 stoichiometry. ${ }^{b}$ Data from ref. ${ }^{10} a$. ${ }^{c}$ Repeat of the experiment outlined in ref. ${ }^{10} \mathrm{a}$ - data from the average of a minimum of two experiments.

In our hands, the coupling of $\boldsymbol{O}$-substituted aldehyde $\mathbf{8}$ under Stetter's conditions did result in a chemoselective process; however, rather than the 
reported formation of $\mathbf{1 4} \mathbf{c}$ as the sole product (entry 4), 14d was identified as the major constituent of the reaction mixture in $64 \%$ yield (entry 5 ). In the triazolium ion-mediated reaction $\mathbf{1 4 d}$ was also formed as the sole product in similar yield (entry 6). It is certain that the assignment of the major product from the reaction involving thiazolium ions as $\mathbf{1 4 c}$ instead of 14d by Stetter is an error, most likely related to the disparate focus of Stetter's study (which concentrated on the mixed oxidized benzil-type products) and the limitations of NMR instrumentation at the time. In the case of the $p$-chlorobenzaldehyde isomer (9), the chemoselectivity profile of the reaction was similar to that observed using benzaldehyde: a low-yielding unselective process was observed in the presence of 18 (entries 7-8), while 19 facilitated the generation of 15d in 63\% yield (entry 9).

Another aspect of Stetter's work we found intriguing was the reversal of the chemoselectivity observed in the presence of $\pi$-excessive heterocyclic aldehydes. For instance, as Stetter had disclosed previously (entry 10), we found that furfural (10) could be added to $\mathbf{1 2}$ in the presence of thiazolium salt $\mathbf{1 8}$ to furnish 16c (via a BI derived from initial attack of the catalyst on the aromatic aldehyde) as the major product in high yield (entry 11). To our surprise, the corresponding reaction catalyzed by the triazoliumderived carbene proved reproducibly inefficient and unselective (entry 12). In addition, thiophene-2carbaldehyde (11) underwent selective crossed AC reactions with 12 in the presence of either 18 or 19 to produce 17c; with the thiazolium salt-derived carbene providing higher product yields (entries 13-15).

It is clear from these investigations that (as expected) $o$-substitution of the benzaldehyde component allows selective crossed AC reactions favoring the crossproduct derived from initial catalyst attack on the aliphatic aldehyde to take place, regardless of the catalyst employed. However, in the absence of an O-substituent the thiazolium precatalyst 18 mediates unselective reactions, whereas the triazolium saltderived carbene is capable of promoting the formation of $15 \mathbf{d}$ as the dominant product in good overall yield.

It would also appear that BIs derived from attack of the carbene on $\pi$-excessive heterocyclic aldehydes are very different in character to those derived from benzaldehydes. Here the thiazolium ion-based catalyst promoted almost completely chemoselective reactions where the major product forms after initial attack on the heterocyclic aldehyde, while in the triazolium case the catalyst behaves differently if presented with either a furan or thiophene-based electrophile; promoting selective reactions in the former case and unselective processes in the latter. Thus a complex picture emerges where chemoselectivity can derive from either catalyst or substrate control, or a confluence of both factors.

Given the important role that the catalyst appears to play in bringing about a chemoselective outcome, we next investigated the use of other precatalysts in the reaction of 9 with 12 under condition set B (Table 2). We began by modifying the triazolium ion structure: precatalyst 20 (an analogue of $\mathbf{1 9}$ in which the pentafluorophenyl unit has been replaced with a phenyl moiety) mediated a relatively unselective crossed AC reaction: while 15c and 15d dominated over homo $\mathrm{AC}$ products $\mathbf{1 5 a}$ and $\mathbf{1 5 b}$, the crossed products were formed in almost equal amounts (entry 1).

The trisubstituted triazolium precatalyst $\mathbf{2 1}$ exhibited a very similar activity (entry 2) and chemoselectivity profile to $\mathbf{2 0}$, while 22 (which is characterized by the presence of two aromatic moieties flanking the acidic central $\mathrm{CH}$-position, one of which is a bulky mesityl group) mediated an almost completely unselective reaction: only the formation of 15a was avoided and the marked increase in the levels of the homo-BC reaction product (i.e. 15b) obtained is noteworthy (entry 3).

Table 2 Crossed AC reactions: investigation of the influence of catalyst structure

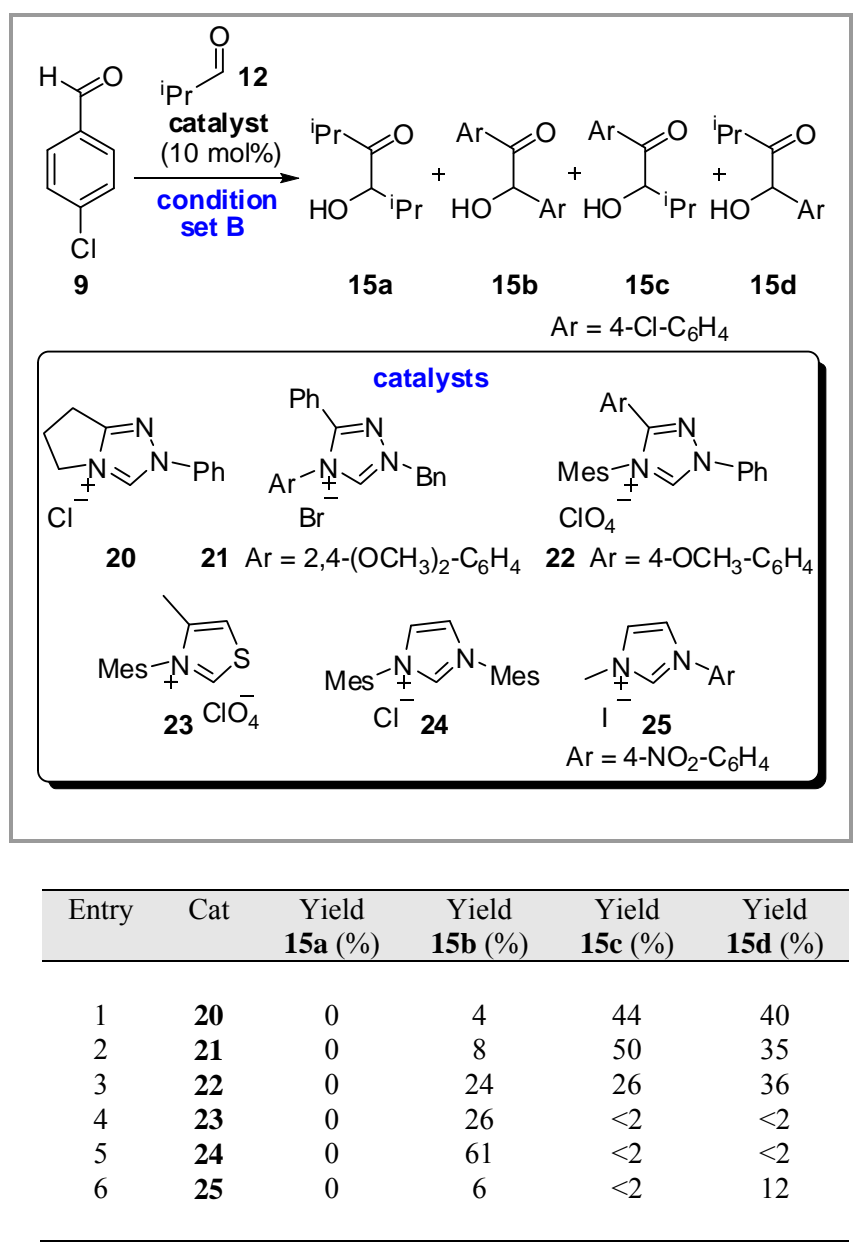

${ }^{a}$ Yield determined by ${ }^{1} \mathrm{H}$ NMR spectroscopy using (E)-stilbene as an internal standard. Note: yields of 15a and $\mathbf{1 5 b}$ account for the 2:1 stoichiometry. 
It is also interesting to note that the mesitylsubstituted thiazolium ion $\mathbf{2 3}$ provided $\mathbf{1 5 b}$ as the sole detectable product in 26\% yield (entry 4). This observation is in stark contrast with the performance of precatalyst catalyst $\mathbf{1 8}$ under condition set A (see Table 1, entries 7-8). Likewise, the bis-mesityl substituted bulky imidazolium ion $\mathbf{2 4}$ did not mediate the crossed AC process at all - only 15b was formed, albeit in moderately good yield (entry 5) while the less bulky 4-nitrophenyl substituted imidazolium ion 25 proved completely unsuitable as a catalyst precursor (entry 6).

From analysis of these results two conclusions can be drawn:

1) The pentafluorophenyl unit plays a key role in controlling selectivity in crossed $\mathrm{AC}$ reactions in the presence of precatalyst 19 all triazolium catalysts (i.e. 20-22) devoid of this substituent failed to promote selective processes.

2) Irrespective of the nature of the heterocyclic core, the presence of bulky groups (in particular the mesityl group) flanking the carbene carbon either significantly diminishes or destroys the catalyst's ability to promote crossed AC reactions. Using these catalyst systems elevated levels of homo BC products are detected.

Table 3 Crossed AC reactions: investigation of the influence of solvent

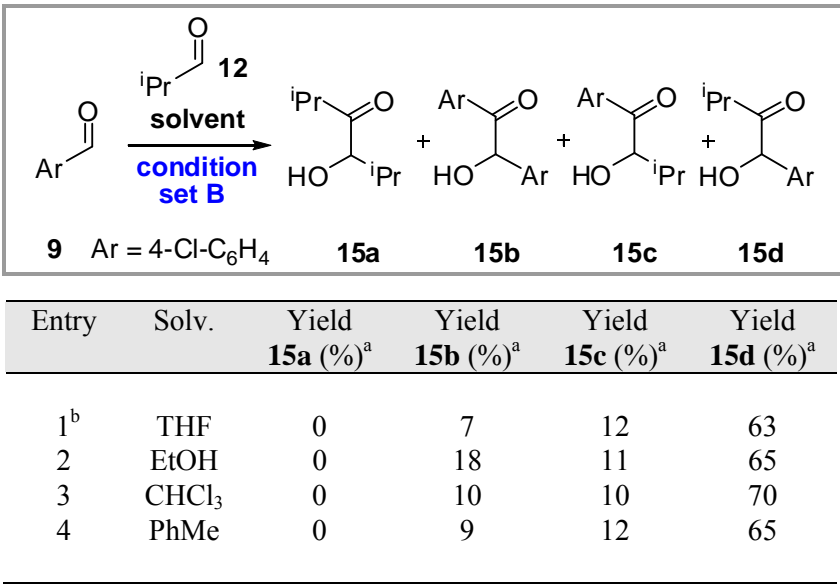

${ }^{\text {a }}$ Yield determined by ${ }^{1} \mathrm{H}$ NMR spectroscopy using (E)-stilbene as an internal standard. Note: yields of 15a and 15b account for the 2:1 stoichiometry. ${ }^{\mathrm{b}}$ Data from Table 1 , entry 9.

Since the crossed BC reaction proceeds through charged intermediates - the stability of which we speculated would be impacted upon by the polarity of the reaction medium - we next evaluated the influence of solvent on the process (Table 3). Surprisingly, it was found that the reaction proceeded with comparable levels of efficiency and chemoselectivity in solvents ranging from the very polar and protic (entries 1 and 2 respectively) to the moderately polar and apolar (entries 3 and 4 respectively).
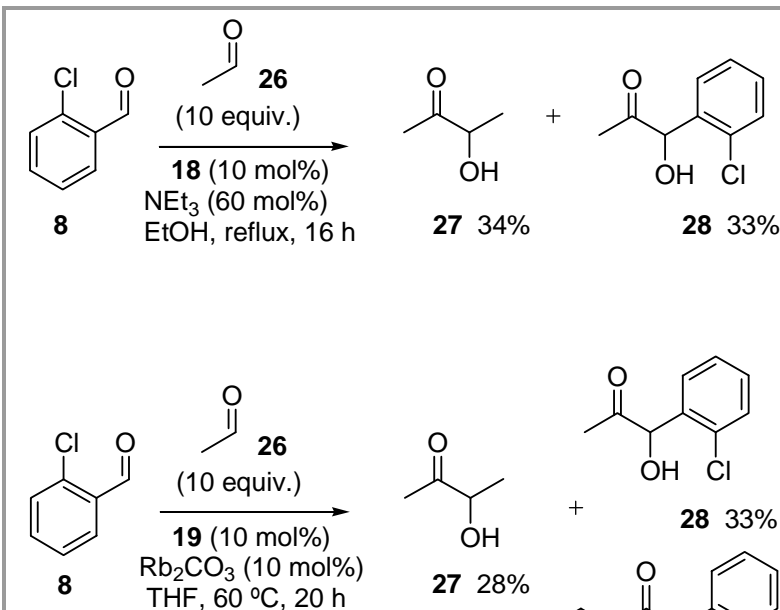<smiles>[Z7][R6]</smiles><smiles>CC(=O)C(O)c1ccccc1Cl</smiles>

$28 \%$<smiles>O=C(c1ccccc1Cl)C(O)c1ccccc1Cl</smiles><smiles>CCCC(=O)C(O)C(=O)c1ccco1</smiles><smiles>O=Cc1ccco1</smiles><smiles>CCCCC(O)C(O)C(=O)c1ccco1</smiles>

$3138 \%$<smiles>O=C(c1ccco1)C(O)c1ccco1</smiles>

16b $10 \%$

The behaviour of unbranched aliphatic aldehydes in these reactions was also briefly examined (Scheme 1). Acetaldehyde (26) could be coupled with 8 in the presence of either the thia- or the triazolium ion precatalyst. The aliphatic partner was required in 10 fold excess due to its volatility. These reactions were inefficient in general: the smaller, less hindered aldehyde readily formed the homodimer 27 in both cases at levels approximately equal to that of the expected crossed product 28. It is perhaps of note that the triazolium precatalyst also mediates the formation of trace amounts of benzoin derivative 14b, which was not observed in the reaction catalyzed by the thiazolium ion derived carbene. In a similar fashion, the reaction between furfural (10) and butanal (29) 
furnished equivalent (but moderate) yields of homodimer $\mathbf{3 0}$ and the crossed-product $\mathbf{3 1}$ under condition set A.

In the presence of the triazolium ion marginally higher yields of 31 were obtained, and again low levels of the dimer derived from homo-BC of 10 (i.e. 16b) were observed. When this reaction is compared to the equivalent transformation involving isobutyraldehyde (i.e. Table 1, entry 12), one notices the absence of the crossed product derived from the initial attack of the catalyst on 29. Presumably this is related to the less hindered nature of 29, which results in all of that BI being converted to homodimer $\mathbf{3 0}$.

The general superiority of catalyst $\mathbf{1 9}$ is further underlined by the finding that the levels of chemoselectivity observed in the presence of $\mathbf{1 8}$ and 19 were very similar, despite the thiazolium system operating under Stetter's original conditions involving the use of 3.0 equivalents of aliphatic aldehyde, while the triazolium dervied carbene mediated reactions in which the aldehydes were present in stoichiometric amounts.

Finally, the potential of $\mathbf{1 9}$ to serve as a catalyst for the promotion of selective and synthetically useful crossed AC reactions involving benzaldehydes devoid of an ortho-substituent was evaluated (Scheme 2). Gratifyingly, lack of steric bulk at the ortho position is no impediment to a chemoselective process in the presence of precatalyst 19 . Reaction of one equivalent of 12 with either an activated or a deactivated benzaldehyde (i.e. 32 and 33) afforded 34 and 35 respectively in good isolated yield. Cyclohexane carbaldehyde (36) could also participate in these processes - reaction with benzaldehyde generated coupled product 37 in $63 \%$ yield.

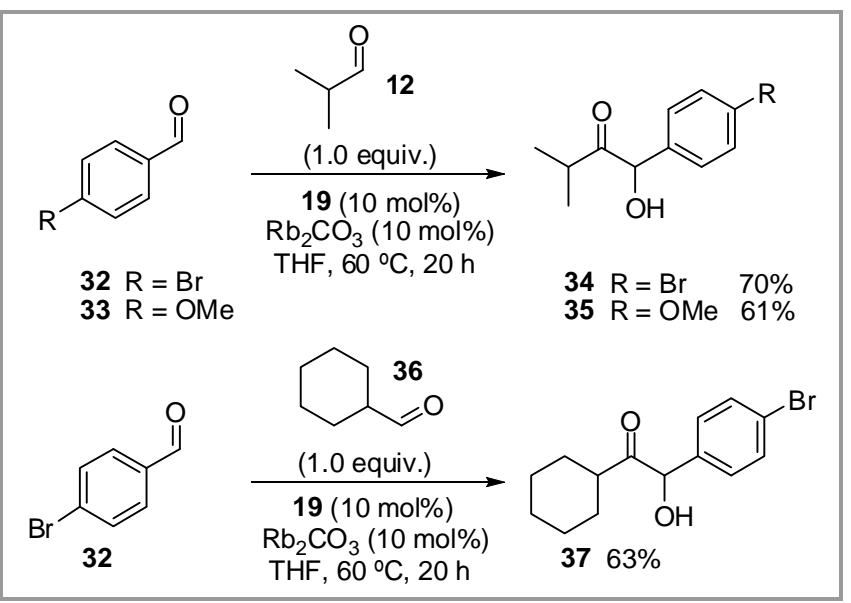

Scheme 2 Crossed AC reactions of unhindered benzaldehydes

In summary, we have evaluated the relative performance of thiazolium and triazolium ion precatalysts in crossed $\mathrm{AC}$ reactions. In general, a complex picture emerges where both catalyst and substrate control play important roles in determining the outcome of the process from both efficiency and chemoselectivity perspectives. The triazolium catalyst 19 proved more useful over a wide range of substrates than its thiazolium counterpart 18, and an error in the literature concerning the performance of $\mathbf{1 8}$ in the reaction to generate $\mathbf{1 4}$ has been corrected.

Substrate features demonstrated to be important in the control of chemoselectivity include the presence of either $o$-substitution or a $\pi$-excessive heterocycle substituted at position 2 in the benzaldehyde component (features which interestingly result in opposing chemoselectivity), and a disubstituted $\alpha$ carbon on the aliphatic aldehyde coupling partner. The requirement for the $O$-substituent on the aromatic aldehyde can be obviated through the use of the triazolium-derived carbene catalyst - in which the pentafluorophenyl moiety and the absence of steric bulk adjacent to the carbene carbon atom were demonstrated to be key factors contributing to highly chemoselective catalysis.

Studies to further explore the interplay between these factors with the aim of developing superior catalyst systems are underway.

\section{Experimental}

Unless otherwise noted, all commercially available compounds were used as provided without further purification. All reactions were carried out under a protective atmosphere of dry nitrogen or argon using oven-dried glassware unless otherwise stated.

NMR spectra were recorded on a Bruker Avance 300 (300.13 MHz), $400 \mathrm{MHz}(400.13 \mathrm{MHz})$ or a Bruker Advance $600(600.13 \mathrm{MHz})$ and using the solvent peak as internal reference $\left(\mathrm{CDCl}_{3}: \delta \mathrm{H} 7.26 ; \delta \mathrm{C} 77.0\right.$ and DMSO- $\mathrm{d}_{6}: \delta$ H 2.51; $\delta$ C 39.5). Multiplicities are indicated, $\mathrm{s}$ (singlet), $\mathrm{d}$ (doublet), $\mathrm{t}$ (triplet), $\mathrm{q}$ (quartet), quint (quintet), app. sept (app. septet), m (multiplet)); coupling constants $(J)$ are in Hertz $(\mathrm{Hz})$. Mass spectra (MS ESI) were recorded using a Micromass/Waters mass spectrometer equipped with a TOF analyser, using ESI, and also with a Finnigan MAT 95 or Varian MAT 311A. All reactions were monitored by thin-layer chromatography using Merck silica gel plates $60 \mathrm{~F}_{254}$; visualization was accomplished with UV light and/or staining with appropriate stains $\left(\mathrm{KMnO}_{4}\right.$, anisaldehyde, vaniline, ninhydrin or phosphomolybdic acid). Standard flash chromatography procedures were followed (particle size $40-63 \mu \mathrm{m}$ ). Infrared spectra were obtained using neat samples on a Perkin Elmer FT-IR spectrometer, respectively on a Biorad Excalibur FTS 3000 Spectrometer equipped with a universal ATR sampling accessory.

Tetrahydrofuran was distilled from sodium/benzophenone. Catalyst 19 was prepared according to the method described by Rovis. ${ }^{20}$ 


\section{General Procedure for Crossed Acyloin Condensation Condition Set A ('Stetter')}

A flame-dried Schlenk flask ('tube shape') ${ }^{21}$ equipped with a magnetic stirring bar was charged with $14 \mathrm{mg}$ $(0.05 \mathrm{mmol}=10 \mathrm{~mol} \%)$ thiazolium iodide precatalyst 18 (and $25 \mathrm{~mol} \%(E)$-stilbene, if required) and placed under high vacuum. After having dried the solids for $1 \mathrm{~h}$ at ambient temperature, $0.16 \mathrm{~mL}$ of $\mathrm{EtOH}$ was added and the resulting solution stirred for $5 \mathrm{~min}$. Now $0.5 \mathrm{mmol}$ ( 1 equiv.) of the aromatic aldehyde as well as $1.5 \mathrm{mmol}$ ( 3 equiv.) of the aliphatic aldehyde were added. After final addition of $0.3 \mathrm{mmol}$ (0.6 equiv) triethylamine, the reaction vessel was equipped with a reflux condenser and heated for $16 \mathrm{~h}$ (ca. $90{ }^{\circ} \mathrm{C}$ ) under an inert atmosphere.

To determine the yields of the benzoin products, residual starting material etc. via quantitative NMR, the reaction vessel was allowed to cool to room temperature. In order to transfer the crude reaction mixture into an NMR tube, a Pasteur-pipette (without cap) was dipped four times into the solution (whereupon it is becoming partly solid in most cases). Finally, an appropriate amount of $\mathrm{CDCl}_{3}$ was added.

For the isolation of the corresponding benzoin products the crude mixture was evaporated and purified by column chromatography.

\section{General Procedure for Crossed Acyloin Condensation Condition Set B}

A flame-dried Schlenk flask equipped with a magnetic stirring bar was charged with $\mathrm{Rb}_{2} \mathrm{CO}_{3}(12 \mathrm{mg}$, $0.05 \mathrm{mmol}$ ). The reaction vessel was evacuated, heated to $650^{\circ} \mathrm{C}$ for $1 \mathrm{~min}$ and cooled to RT under $\mathrm{N}_{2}$. After this procedure had been repeated once, triazolium-precatalyst $19(18 \mathrm{mg}, 0.05 \mathrm{mmol})$ was added. The precatalyst/base-mixture was placed under vacuum and dried at RT for $1 \mathrm{~h}$. Subsequently, absolute THF $(0.45 \mathrm{ml})$ was added and the resulting mixture was allowed to stir at RT for $15 \mathrm{~min}$. After sequential addition of the appropriate aromatic aldehyde $(0.5 \mathrm{mmol})$ and $\alpha$-branched aldehyde $(0.5 \mathrm{mmol})$, the reaction vessel was equipped with a reflux condenser and stirred at $60^{\circ} \mathrm{C}$ for $20 \mathrm{~h}$ under an atmosphere of $\mathrm{N}_{2}$. The reaction mixture was allowed to cool to RT, followed by evaporation of the solvent under reduced pressure. The crude product was purified by column chromatography (silica gel, solvent mixture as indicated).

\section{2-Hydroxy-1,2-diphenyl-ethanone (13b) \\ $\mathrm{Mp} \mathrm{131-132}{ }^{\circ} \mathrm{C}$ (Lit. ${ }^{8 \mathbf{f}, 22 a}$ 131-132 ${ }^{\circ} \mathrm{C}$ ); $R_{f}\left(\mathrm{CH}_{2} \mathrm{Cl}_{2} /\right.$ hexane $\left.3 / 2\right)=0.2$.}

${ }^{1} \mathrm{H}$ NMR $\left(400 \mathrm{MHz}, \mathrm{CDCl}_{3}\right) \delta=7.95(\mathrm{~d}, J=8.0 \mathrm{~Hz}$, 2H), 7.55 (t, $J=8.0 \mathrm{~Hz}, 1 \mathrm{H}), 7.43$ (app. t, 2H), 7.29-
7.40 (m, 5H (overlapping with $\mathrm{CHCl}_{3}$ resonance)), $5.98(\mathrm{~s}, 1 \mathrm{H}), 4.58(\mathrm{bs}, 1 \mathrm{H})$.

\section{2-Hydroxy-3-methyl-1-phenylbutan-1-one (13c)}

according to the general procedure 'Cond. Set A': yield after column chromatography (silica gel, n-pentane/Et $\mathrm{t}_{2} \mathrm{O}$ 10/1) $17 \mathrm{mg}$ (19\%), colourless oil.

$R_{f}\left(n\right.$-pentane $\left./ \mathrm{Et}_{2} \mathrm{O} 5 / 1\right)=0.28$.

IR (neat): 3490, 2964, 2930, 1676, 1449, 1263, 1137, $1034,990,760,693,532,497 \mathrm{~cm}^{-1}$.

${ }^{1} \mathrm{H}$ NMR $\left(300 \mathrm{MHz}, \mathrm{CDCl}_{3}\right): \delta=7.94-7.86(\mathrm{~m}, 2 \mathrm{H})$, $7.66-7.58(\mathrm{~m}, 1 \mathrm{H}), 7.54-7.46(\mathrm{~m}, 2 \mathrm{H}), 4.98(\mathrm{dd}, J$ $=6.3 \mathrm{~Hz}, 2.5 \mathrm{~Hz}, 1 \mathrm{H}), 3.61(\mathrm{~d}, J=6.3 \mathrm{~Hz}, 1 \mathrm{H}), 2.13$ (app. sept-d, $J=6.8 \mathrm{~Hz}, 2.6 \mathrm{~Hz}, 1 \mathrm{H}), 1.17$ (d, $J=7.1$ $\mathrm{Hz}, 3 \mathrm{H}), 0.65$ (d, $J=6.9 \mathrm{~Hz}, 3 \mathrm{H})$.

${ }^{13} \mathrm{C}-\mathrm{NMR}\left(75.5 \mathrm{MHz}, \mathrm{CDCl}_{3}\right): \delta=202.3,134.2$, $133.9,128.9,128.5,77.3,32.7,20.2,14.4$.

\section{1-Hydroxy-3-methyl-1-phenylbutan-2-one (13d)}

according to the general procedure 'Cond. Set B': yield after column chromatography (silica gel, $n$-pentane/ $\mathrm{Et}_{2} \mathrm{O}$ 10/1): $48 \mathrm{mg}$ (54\%), colourless to pale yellow crystals.

$\mathrm{Mp} 44-45^{\circ} \mathrm{C} ; R_{\mathrm{f}}\left(n\right.$-pentane $\left./ \mathrm{Et}_{2} \mathrm{O} 5 / 1\right)=0.19$.

IR (neat): 3440, 3402, 2976, 1707, 1455, 1384, 1129, $1011,839,756,722,697,507 \mathrm{~cm}^{-1}$.

${ }^{1} \mathrm{H}$ NMR $\left(300 \mathrm{MHz}, \mathrm{CDCl}_{3}\right): \delta=7.42-7.27(\mathrm{~m}, 5 \mathrm{H})$, $5.22(\mathrm{~d}, J=4.7 \mathrm{~Hz}, 1 \mathrm{H}), 4.39(\mathrm{~d}, J=4.7 \mathrm{~Hz}, 1 \mathrm{H}), 2.70$ (app. sept, $J=7.0 \mathrm{~Hz}, 1 \mathrm{H}), 1.14(\mathrm{~d}, J=6.9 \mathrm{~Hz}, 3 \mathrm{H})$, $0.83(\mathrm{~d}, J=6.6 \mathrm{~Hz}, 3 \mathrm{H})$.

${ }^{13} \mathrm{C}$ NMR $\left(75.5 \mathrm{MHz}, \mathrm{CDCl}_{3}\right): \delta=213.5,137.9$, 129.0, 128.7, 127.6, 78.3, 36.0, 19.4, 18.0.

HRMS (EI): $m / z$ [M] calcd. for $\mathrm{C}_{11} \mathrm{H}_{14} \mathrm{O}_{2}:$ 178.0994, found: 178.0996 .

1,2-Bis-(2-chloro-phenyl)-2-hydroxy-ethanone (14b) Mp 65-66 ${ }^{\circ} \mathrm{C}$ (Lit. $\left.{ }^{\text {8f, 22b }} 64-66{ }^{\circ} \mathrm{C}\right) ; R_{f}\left(\mathrm{CH}_{2} \mathrm{Cl}_{2} /\right.$ hexane $3 / 2)=0.2$.

${ }^{1} \mathrm{H}$ NMR $\left(400 \mathrm{MHz}, \mathrm{CDCl}_{3}\right) \delta=7.31-7.40(\mathrm{~m}, 3 \mathrm{H})$, 7.23-7.26 (m, 5H (overlapping with $\mathrm{CHCl}_{3}$ resonance)), $6.38(\mathrm{~s}, 1 \mathrm{H}), 4.46(\mathrm{bs}, 1 \mathrm{H})$.

\section{1-(2-Chlorophenyl)-1-hydroxy-3-methylbutan-2- one (14d)}

according to the general procedure 'Cond. Set B': yield after column chromatography (silica gel, $n$-pentane/ $\mathrm{Et}_{2} \mathrm{O}$ 10/1): $75 \mathrm{mg}$ (71\%), pale yellow oil

$\mathrm{R}_{\mathrm{f}}\left(n\right.$-pentane $\left./ \mathrm{Et}_{2} \mathrm{O} 5 / 1\right)=0.25$.

IR (neat): 3440, 2973, 1713, 1473, 1385, 1015, 758, $632,536,499 \mathrm{~cm}^{-1}$. 
${ }^{1} \mathrm{H}$ NMR $\left(300 \mathrm{MHz}, \mathrm{CDCl}_{3}\right): \delta=7.45-7.38(\mathrm{~m}, 1 \mathrm{H})$, $7.30-7.18(\mathrm{~m}, 3 \mathrm{H}), 5.73(\mathrm{~d}, J=4.4 \mathrm{~Hz}, 1 \mathrm{H}), 4.41(\mathrm{~d}$, $J=4.7 \mathrm{~Hz}, 1 \mathrm{H}), 2.70$ (app. sept, $J=6.9 \mathrm{~Hz}, 1 \mathrm{H}), 1.17$ (d, $J=7.1 \mathrm{~Hz}, 3 \mathrm{H}), 0.88(\mathrm{~d}, J=6.9 \mathrm{~Hz}, 3 \mathrm{H})$.

${ }^{13} \mathrm{C}$ NMR (75.5 MHz, $\left.\mathrm{CDCl}_{3}\right): \delta=212.9,135.7$, $133.8,130.1,129.9,129.3,127.5,74.6,36.2,19.5$, 17.9 .

HRMS (ESI): $m / z[\mathrm{M}+\mathrm{H}]^{+}$calcd. for $\mathrm{C}_{11} \mathrm{H}_{14} \mathrm{ClO}_{2}$ : 213.0682, found: 213.0686 .

\section{1-(4-Chlorophenyl)-2-hydroxy-3-methylbutan-1- one (15c)}

according to the general procedure 'Cond. Set A': yield after column chromatography (silica gel, n-pentane/ $\mathrm{Et}_{2} \mathrm{O}$ 20/1): $20 \mathrm{mg}$ (19\%), pale yellow oil.

$R_{f}\left(n\right.$-pentane $\left./ \mathrm{Et}_{2} \mathrm{O} 5 / 1\right)=0.22$.

IR (neat): 3483, 2961, 2930, 2873, 1669, 1589, 1491, 1387, 1307, 1279, 1258, 1090, 1032, 939, 807, 605, $532,460 \mathrm{~cm}^{-1}$.

${ }^{1} \mathrm{H}$ NMR $\left(300 \mathrm{MHz}, \mathrm{CDCl}_{3}\right): \delta=7.88-7.81(\mathrm{~m}, 2 \mathrm{H})$, $7.52-7.44(\mathrm{~m}, 2 \mathrm{H}), 4.93(\mathrm{dd}, J=6.6 \mathrm{~Hz}, 2.5 \mathrm{~Hz}, 1 \mathrm{H})$, 3.53 (d, $J=6.6 \mathrm{~Hz}, 1 \mathrm{H}), 2.10$ (app. sept-d, $J=6.8 \mathrm{~Hz}$, $2.6 \mathrm{~Hz}, 1 \mathrm{H}), 1.17(\mathrm{~d}, J=7.1 \mathrm{~Hz}, 3 \mathrm{H}), 0.65$ (d, $J=6.6$ $\mathrm{Hz}, 3 \mathrm{H})$.

${ }^{13} \mathrm{C}$ NMR $\left(75.5 \mathrm{MHz}, \mathrm{CDCl}_{3}\right): \delta=201.1,140.4$, $132.4,129.9,129.3,77.3,32.7,20.1,14.4$.

HRMS (EI): $m / z \quad[\mathrm{M}]^{+}$calcd.for $\mathrm{C}_{11} \mathrm{H}_{13} \mathrm{ClO}_{2}$ : 212.0604, found: 212.0599 .

\section{1-(4-Chlorophenyl)-1-hydroxy-3-methylbutan-2- one (15d)}

according to the general procedure 'Cond. Set B': yield after column chromatography (silica gel, $n$-pentane $/ \mathrm{Et}_{2} \mathrm{O}$ 10/1): $62 \mathrm{mg}$ (58\%), colourless crystals.

$\mathrm{Mp} 45-46{ }^{\circ} \mathrm{C} ; R_{f}\left(n\right.$-pentane $\left./ \mathrm{Et}_{2} \mathrm{O} 5 / 1\right)=0.14$.

IR (neat) : 3426, 2968, 2934, 1711, 1592, 1491, 1386, $1213,1093,1013,808,534,480 \mathrm{~cm}^{-1}$.

${ }^{1} \mathrm{H}$ NMR $\left(300 \mathrm{MHz}, \mathrm{CDCl}_{3}\right): \delta=7.39-7.33(\mathrm{~m}, 2 \mathrm{H})$, $7.28-7.23(\mathrm{~m}, 2 \mathrm{H}), 5.19$ (d, $J=4.7 \mathrm{~Hz}, 1 \mathrm{H}), 4.37$ (d, $J=4.7 \mathrm{~Hz}, 1 \mathrm{H}), 2.68$ (app. sept, $J=6.9 \mathrm{~Hz}, 1 \mathrm{H}$ ), 1.13 $(\mathrm{d}, J=6.9 \mathrm{~Hz}, 3 \mathrm{H}), 0.85(\mathrm{~d}, J=6.6 \mathrm{~Hz}, 3 \mathrm{H})$.

${ }^{13} \mathrm{C}$ NMR (75.5 MHz, $\left.\mathrm{CDCl}_{3}\right): \delta=213.0,136.5$, 134.7, 129.2, 128.9, 77.6, 36.0, 19.4, 18.0.

HRMS (EI): $m / z \quad[M]^{+}$calcd. for $\mathrm{C}_{11} \mathrm{H}_{13} \mathrm{ClO}_{2}$ : 212.0604, found: 212.0605 .

\section{1,2-Di-furan-2-yl-2-hydroxy-ethanone (16b)}

Mp 137-138 ${ }^{\circ} \mathrm{C}\left(\right.$ Lit. $\left.^{22} 135-136{ }^{\circ} \mathrm{C}\right), R_{f}\left(\mathrm{CH}_{2} \mathrm{Cl}_{2}\right)=$ 0.2 .

${ }^{1} \mathrm{H}$ NMR (400 MHz, $\left.\mathrm{CDCl}_{3}\right) \delta=7.63$ (app. s, 1H), $7.39(\mathrm{~d}, J=1.5 \mathrm{~Hz}, 1 \mathrm{H})$, ), 7.27 (m, $1 \mathrm{H}$ (overlapping with $\mathrm{CHCl}_{3}$ resonance) $), 6.56(\mathrm{dd}, J=4.0,2.2 \mathrm{~Hz}$,
$1 \mathrm{H}), 6.42(\mathrm{~d}, J=3.5 \mathrm{~Hz}, 1 \mathrm{H}), 6.37(\mathrm{dd}, J=3.0,1.5 \mathrm{~Hz}$, $1 \mathrm{H}), 5.82(\mathrm{bs}, 1 \mathrm{H}), 4.22(\mathrm{bs}, 1 \mathrm{H})$.

\section{1-(Furan-2-yl)-2-hydroxy-3-methylbutan-1-one (16c)}

according to the general procedure 'Cond. Set A': yield after column chromatography (silica gel, $n$-pentane/ $\mathrm{Et}_{2} \mathrm{O}$ 10/1): $30 \mathrm{mg}$ (36\% - not optimized), yellowish crystals.

Mp 36-37 ${ }^{\circ} \mathrm{C} ; R_{f}\left(n\right.$-pentane $\left./ \mathrm{Et}_{2} \mathrm{O} 5 / 1\right)=0.11$.

IR (neat) : 3442, 3126, 2975, 2933, 1656, 1466, 1410 , $1270,1146,1030,990,814,764,589,510 \mathrm{~cm}^{-1}$.

${ }^{1} \mathrm{H}$ NMR $\left(300 \mathrm{MHz}, \mathrm{CDCl}_{3}\right): \delta=7.60-7.57(\mathrm{~m}, 1 \mathrm{H})$, $7.28-7.23(\mathrm{~m}, 1 \mathrm{H}), 6.54(\mathrm{dd}, J=3.6 \mathrm{~Hz}, 1.6 \mathrm{~Hz}, 1 \mathrm{H})$, 4.67 (br s, 1H), $3.38-3.25$ (m, 1H), 2.20 (app. sept-d, $J=6.9 \mathrm{~Hz}, 2.7 \mathrm{~Hz}, 1 \mathrm{H}), 1.10(\mathrm{~d}, J=6.9 \mathrm{~Hz}, 3 \mathrm{H}), 0.69$ (d, $J=6.6 \mathrm{~Hz}, 3 \mathrm{H})$.

${ }^{13} \mathrm{C}$ NMR (75.5 MHz, $\left.\mathrm{CDCl}_{3}\right): \delta=190.6,150.6$, 147.0, 118.8, 112.5, 77.7, $32.720 .0,14.8$.

MS (EI): $m / z(\%)=168(1)\left[\mathrm{M}^{+\bullet}\right], 167(5)\left[\mathrm{M}^{+\bullet}-\mathrm{H}^{\bullet}\right]$, 150 (2) $\left[\mathrm{M}^{+\bullet}-\mathrm{H}_{2} \mathrm{O}\right], 97(40)\left[\mathrm{M}^{+\bullet}-\mathrm{C}_{4} \mathrm{H}_{7} \mathrm{O}^{+}\right]$.

\section{1-(Furan-2-yl)-1-hydroxy-3-methylbutan-2-one (16d)}

according to the general procedure 'Cond. Set $B$ ' (here: $2 \mathrm{mmol}$ ): yield after column chromatography (silica gel, petroleum ether/ethyl acetate 10/1): $16 \mathrm{mg}$ (5\% - not optimized), yellow oil.

$R_{f}($ petroleum ether/ethyl acetate $5 / 1)=0.29$.

${ }^{1} \mathrm{H}$ NMR $\left(300 \mathrm{MHz}, \mathrm{CDCl}_{3}\right): \delta=7.40$ (br s, 1H), 6.42 $-6.36(\mathrm{~m}, 2 \mathrm{H}), 5.28(\mathrm{~d}, J=5.2 \mathrm{~Hz}, 1 \mathrm{H}), 4.15(\mathrm{~d}, J=$ $4.9 \mathrm{~Hz}, 1 \mathrm{H}), 2.71$ (app. sept, $J=6.9 \mathrm{~Hz}, 1 \mathrm{H}), 1.13$ (d, $J=7.1 \mathrm{~Hz}, 3 \mathrm{H}), 0.96(\mathrm{~d}, J=6.9 \mathrm{~Hz}, 3 \mathrm{H})$.

${ }^{13} \mathrm{C}$ NMR (75.5 MHz, $\left.\mathrm{CDCl}_{3}\right): \delta=211.0,150.6$, 143.2, 110.9, 109.6, 71.4, 36.4, 19.2, 17.6.

\section{2-Hydroxy-3-methyl-1-(thiophen-2-yl)butan-1-one (17c)}

according to the general procedure 'Cond. Set A': yield after column chromatography (silica gel, $n$ pentane/ $\left.\mathrm{Et}_{2} \mathrm{O} 20 / 1\right)$ : $40 \mathrm{mg}$ (43\%), colourless to pale yellow needles.

Mp 37-38 ${ }^{\circ} \mathrm{C} ; R_{f}\left(n-p e n t a n e / \mathrm{Et}_{2} \mathrm{O} 5 / 1\right)=0.17$.

IR (neat): 3506, 3470, 3085, 2970, 2930, 2873, 1646, 1518,1412 , 1359, 1260, 1139, 1063, 1019, 908, 813, $749,689,472,430 \mathrm{~cm}^{-1}$.

${ }^{1} \mathrm{H}$ NMR $\left(300 \mathrm{MHz}, \mathrm{CDCl}_{3}\right): \delta=7.79-7.69(\mathrm{~m}, 2 \mathrm{H})$, $7.20-7.14(\mathrm{~m}, 1 \mathrm{H}), 4.77$ (dd, $J=6.9 \mathrm{~Hz}, 2.7 \mathrm{~Hz}, 1 \mathrm{H})$, 3.42 (d, $J=6.9 \mathrm{~Hz}, 1 \mathrm{H}), 2.22$ (app. sept-d, $J=6.8 \mathrm{~Hz}$, $2.9 \mathrm{~Hz}, 1 \mathrm{H}), 1.16(\mathrm{~d}, J=7.1 \mathrm{~Hz}, 3 \mathrm{H}), 0.75$ (d, $J=6.9 \mathrm{~Hz}$, $3 \mathrm{H})$.

${ }^{13} \mathrm{C}$ NMR (75.5 MHz, $\left.\mathrm{CDCl}_{3}\right): \delta=194.5,140.3$, 134.6, 132.9, 128.3, 78.3, 34.0, 20.1, 14.8 . 
HRMS (EI): $m / z[M]^{+}$calcd. for $\mathrm{C}_{9} \mathrm{H}_{12} \mathrm{SO}_{2}: 184.0558$, found: 184.0558 .

\section{3-Hydroxybutan-2-one (27)}

according to the general procedure 'Cond. Set A': yield after column chromatography (silica gel, hexane/Et $\left.{ }_{2} \mathrm{O} 4 / 1\right): 30 \mathrm{mg}$ (30\%), colourless liquid

$R_{f}\left(\right.$ silica gel, hexane $\left./ \mathrm{Et}_{2} \mathrm{O} 4 / 1\right)=0.13$.

IR (neat): 3454, 2924, 1690, 1460, 1052, $732 \mathrm{~cm}^{-1}$.

${ }^{1} \mathrm{H}$ NMR (600 MHz, $\left.\mathrm{CDCl}_{3}\right): \delta 4.28(\mathrm{dq}, J=7.2, J=$ $4.3 \mathrm{~Hz}, 1 \mathrm{H}), 3.53(\mathrm{~d}, J=4.3 \mathrm{~Hz}, 1 \mathrm{H}, \mathrm{OH}), 2.23$ (s, $3 \mathrm{H}) .1 .43(\mathrm{~d}, J=7.2 \mathrm{~Hz}, 3 \mathrm{H}), 1.28(\mathrm{~s}, 3 \mathrm{H})$.

${ }^{13} \mathrm{C}$ NMR $\left(150 \mathrm{MHz}, \mathrm{CDCl}_{3}\right): \delta 210.0,72.8,24.7$, 19.5 .

HRMS (EI): $m / z[M]^{+}$calcd. for $\mathrm{C}_{4} \mathrm{H}_{8} \mathrm{O}_{2}: 88.1096$, found: 88.1109 .

\section{1-(2-Chlorophenyl)-1-hydroxypropan-2-one (28)}

according to the general procedure 'Cond. Set $A$ ': yield after column chromatography (silica gel, hexane/Et $\left.{ }_{2} \mathrm{O} 4 / 1\right)$ : $62 \mathrm{mg}$ (33\%), yellow oil

$R_{f}\left(\right.$ silica gel, hexane $\left./ \mathrm{Et}_{2} \mathrm{O} 4 / 1\right)=0.16$.

IR (neat): 3447, 1716, 1592, 1474, 1358, 1225, 1179 , $1035,966,885,752,688 \mathrm{~cm}^{-1}$.

${ }^{1} \mathrm{H}$ NMR (400 MHz, $\left.\mathrm{CDCl}_{3}\right): \delta 7.45-7.43(\mathrm{~m}, 1 \mathrm{H})$, 7.31-7.29 (m, 3H), $5.61(\mathrm{~d}, J=4.3 \mathrm{~Hz}, 1 \mathrm{H}), 4.38$ (d, $J=4.3 \mathrm{~Hz}, 1 \mathrm{H}, \mathrm{OH}), 2.15(\mathrm{~s}, 3 \mathrm{H})$.

${ }^{13} \mathrm{C}$ NMR $\left(100 \mathrm{MHz}, \mathrm{CDCl}_{3}\right): \delta 206.2,135.7,133.4$, 130.0, 129.9, 128.9, 127.5, 76.4, 25.2.

HRMS (CI): $m / z \quad[M+H]^{+}$calcd. for $\mathrm{C}_{9} \mathrm{H}_{9} \mathrm{ClO}_{2}$ : 185.0369, found: 185.0366 .

\section{5-Hydroxyoctan-4-one (30)}

according to the general procedure 'Cond. Set A': yield after column chromatography (silica gel, hexane/ $\mathrm{Et}_{2} \mathrm{O}$ 4/1): $41 \mathrm{mg}(28 \%)$.

$R_{f}\left(\right.$ silica gel, hexane $\left./ \mathrm{Et}_{2} \mathrm{O} 4 / 1\right)=0.15$.

IR (neat): 3474, 2961, 1708, 1459, 1275, 1080, 852, $742 \mathrm{~cm}^{-1}$.

${ }^{1} \mathrm{H}$ NMR $\left(600 \mathrm{MHz}, \mathrm{CDCl}_{3}\right): \delta 4.20-4.16(\mathrm{~m}, 1 \mathrm{H})$, $3.52(\mathrm{~d}, J=5.0 \mathrm{~Hz}, 1 \mathrm{H}, \mathrm{OH}), 2.53-2.38(\mathrm{~m}, 2 \mathrm{H}), 1.84-$ $1.75(\mathrm{~m}, 1 \mathrm{H}), 1.72-1.65(\mathrm{~m}, 2 \mathrm{H}), 1.57-1.35(\mathrm{~m}, 3 \mathrm{H})$, 0.98-0.93 (m, 6H).

${ }^{13} \mathrm{C}$ NMR $\left(150 \mathrm{MHz}, \mathrm{CDCl}_{3}\right): \delta 212.2,76.1,39.6$, 35.7, 18.0, 17.0, 13.7, 13.6.

HRMS (EI): $m / z[M]^{+}$calcd. for $\mathrm{C}_{8} \mathrm{H}_{16} \mathrm{O}_{2}: 144.1150$, found: 144.1144 .

\section{1-(Furan-2-yl)-2-hydroxypentan-1-one (31)}

according to the general procedure 'Cond. Set A': yield after column chromatography (silica gel, hexane/ $\mathrm{Et}_{2} \mathrm{O}$ 4/1): $47 \mathrm{mg}(28 \%)$.

Mp $63-66{ }^{\circ} \mathrm{C} R_{f}$ (silica gel, hexane $\left./ \mathrm{Et}_{2} \mathrm{O} 4 / 1\right)=0.18$.

${ }^{1} \mathrm{H}$ NMR (600 MHz, $\left.\mathrm{CDCl}_{3}\right): \delta 7.6(\mathrm{~s}, 1 \mathrm{H}), 7.33(\mathrm{~d}, J=$ $3.5 \mathrm{~Hz}, 1 \mathrm{H}), 6.62(\mathrm{dd}, J=3.5,1.5 \mathrm{~Hz}, 1 \mathrm{H}), 4.86(\mathrm{~m}$, $1 \mathrm{H}), 3.47$ (d, J=5.5 Hz 1H, OH), $1.94-1.87$ (m, 1H), $1.68-1.45(\mathrm{~m}, 3 \mathrm{H}), 0.97(\mathrm{t}, J=7.0 \mathrm{~Hz}, 3 \mathrm{H})$.

${ }^{13} \mathrm{C}$ NMR $\left(150 \mathrm{MHz}, \mathrm{CDCl}_{3}\right): \delta 190.3,149.8,146.6$, 118.4, 112.1, 72.9, 37.3, 17.4, 13.4.

HRMS (ES): $m / z \quad[M+N a]^{+}$calcd. for $\mathrm{C}_{9} \mathrm{H}_{12} \mathrm{O}_{3}$ : 191.0684, found: 191.0691

\section{1-(4-Bromophenyl)-1-hydroxy-3-methylbutan-2- one (34)}

according to the general procedure 'Cond. Set B': yield after column chromatography (silica gel, $n$-pentane/ $\mathrm{Et}_{2} \mathrm{O}$ 10/1): $90 \mathrm{mg}$ (70\%).

$\mathrm{Mp} 58-59^{\circ} \mathrm{C} ; R_{f}$ (silica gel, $n$-pentane $\left./ \mathrm{Et}_{2} \mathrm{O} 5 / 1\right)=$ 0.14 .

IR (neat): 3436, 2968, 1709, 1588, 1486, 1385, 1223, $1008,806,741,641,581,521 \mathrm{~cm}^{-1}$.

${ }^{1} \mathrm{H}$ NMR $\left(300 \mathrm{MHz}, \mathrm{CDCl}_{3}\right): \delta=7.53-7.47(\mathrm{~m}, 2 \mathrm{H})$, $7.22-7.15$ (m, 2H), 5.17 (d, $J=4.7 \mathrm{~Hz}, 1 \mathrm{H}), 4.39$ (d, $J=4.7 \mathrm{~Hz}, 1 \mathrm{H}$ ), 2.67 (app. sept, $J=6.9 \mathrm{~Hz}, 1 \mathrm{H}), 1.13$ $(\mathrm{d}, J=7.1 \mathrm{~Hz}, 3 \mathrm{H}), 0.84(\mathrm{~d}, J=6.6 \mathrm{~Hz}, 3 \mathrm{H})$.

${ }^{13} \mathrm{C}$ NMR $\left(75.5 \mathrm{MHz}, \mathrm{CDCl}_{3}\right): \delta=212.9,137.0$, 132.1, 129.2, 122.8, 77.6, 36.0, 19.4, 18.0.

HRMS (EI): $m / z \quad[M]^{+}$calcd. for $\mathrm{C}_{11} \mathrm{H}_{13} \mathrm{BrO}_{2}$ : 256.0099, found: 256.0109.

\section{1-Hydroxy-1-(4-methoxyphenyl)-3-methylbutan-2-} one (35)

according to the general procedure 'Cond. Set B': yield after column chromatography (silica gel, hexane/ $\mathrm{Et}_{2} \mathrm{O}$ 4/1): $126 \mathrm{mg}(61 \%)$.

Mp $83-85^{\circ} \mathrm{C}: R_{f}\left(\right.$ silica gel, hexane $\left./ \mathrm{Et}_{2} \mathrm{O} 4 / 1\right)=0.17$. IR (neat): 3432, 2967, 1711, 1587, 1455, 1382, 1222 , $1009,813,784,731,692,531 \mathrm{~cm}^{-1}$.

${ }^{1} \mathrm{H}$ NMR (400 MHz, $\left.\mathrm{CDCl}_{3}\right): \delta 7.65(\mathrm{~d}, J=8.9 \mathrm{~Hz}$, 2H), 6.92 (d, $J=8.9 \mathrm{~Hz}, 2 \mathrm{H}), 5.19$ (d, $J=4.5 \mathrm{~Hz}$, $1 \mathrm{H}), 4.35$ (d, J=4.5 Hz , 1H, OH), 3.83 (s, 3H), 2.71 (app. sept, J = 6.7 Hz 1H), $1.14(\mathrm{~d}, J=7.2 \mathrm{~Hz}, 3 \mathrm{H})$, $0.86(\mathrm{~d}, J=6.9 \mathrm{~Hz}, 3 \mathrm{H})$.

${ }^{13} \mathrm{C}$ NMR $\left(100 \mathrm{MHz}, \mathrm{CDCl}_{3}\right): \delta 213.3,159.4,129.5$, 128.4, 114.0, 77.3, 54.8, 35.5, 18.9, 17.5.

HRMS (EI): $m / z[M]^{+}$calcd. for $\mathrm{C}_{12} \mathrm{H}_{16} \mathrm{O}_{3}: 208.1099$, found: 208.1097 .

2-(4-Bromophenyl)-1-cyclohexyl-2-hydroxyethanone (37) 
according to the general procedure 'Cond. Set B': yield after column chromatography (silica gel, petroleum ether/ethylacetate 10/1): $93 \mathrm{mg}$ (63\%), colourless solid

Mp $102-103 \quad{ }^{\circ} \mathrm{C}: \quad R_{f}$ (silica gel, petroleum ether/ethylacetate $5 / 1)=0.29$.

IR(neat): 3430, 2930, 2851, 1705, 1447, 1059, 993, $820,638,521 \mathrm{~cm}^{-1}$.

${ }^{1} \mathrm{H}$ NMR $\left(300 \mathrm{MHz}, \mathrm{CDCl}_{3}\right): \delta 7.52-7.46(\mathrm{~m}, 2 \mathrm{H})$, $7.21-7.13(\mathrm{~m}, 2 \mathrm{H}), 5.14(\mathrm{~d}, J=4.7 \mathrm{~Hz}, 1 \mathrm{H}), 4.39(\mathrm{~d}, J=$ $4.7 \mathrm{~Hz}, 1 \mathrm{H}), 2.39$ (tt, $J=11.3 \mathrm{~Hz}, 3.5 \mathrm{~Hz}, 1 \mathrm{H}), 1.91-1.72$ $(\mathrm{m}, 2 \mathrm{H}), 1.68-1.56(\mathrm{~m}, 2 \mathrm{H}), 1.44-0.94(\mathrm{~m}, 6 \mathrm{H})$.

${ }^{13} \mathrm{C}$ NMR $\left(75,5 \mathrm{MHz}, \mathrm{CDCl}_{3}\right): \delta 211.9,137.0,132.1$, 129.3, 122.8, 77.6, 46.0, 29.6, 27.9, 25.6, 25.5, 25.0.

HRMS (EI): $\mathrm{m} / \mathrm{z} \quad[\mathrm{M}]^{+}$calcd. for $\mathrm{C}_{14} \mathrm{H}_{17} \mathrm{BrO}_{2}$ : 296.0412, found: 296.0410 .

\section{Acknowledgment}

We are grateful to the Irish Research Council for Science Engineering and Technology (IRCSET) and the DFG (German Research Foundation) for financial support.

\section{References}

(1) Wöhler, F.; Liebig, F. Ann. Pharm. 1832, 3, 249.

(2) For recent reviews see: (a) Moore, J. L.; Rovis, T. Top. Curr. Chem. 2009, 291, 77. (b) Enders, D. J. Org. Chem. 2008, 73, 7857. (c) Rovis, T. Chem. Lett. 2008, 37, 1. (d) Zeitler, K. E. Schering Found. Symp. Proc. 2007, 2, 183. (e) Enders, D.; Niemeier, O.; Henseler, A. Chem. Rev. 2007, 107, 5506. (f) Marion, N.; Diez-Gonzalez, S.; Nolan, S. P. Angew. Chem., Int. Ed. 2007, 46, 2988. (g) Zeitler, K. Angew. Chem., Int. Ed. 2005, 44, 7506. (h) Christmann, M. Angew. Chem., Int. Ed. 2005, 44, 2632. (i) Enders, D.; Balensiefer, T. Acc. Chem. Res. 2004, 37, 534. (j) Johnson, J. S. Angew. Chem., Int. Ed. 2004, 43, 1326.

(3) Ukai, T.; Tanaka R.; Dokawa, T. J. Pharm. Soc. Jpn. 1943, 63, 269.

(4) Breslow, R. J. Am. Chem. Soc. 1958, 80, 3719.

(5) Leeper later carried out a detailed kinetic study of the process, see: White, M. J.; Leeper, F. J. J. Org. Chem. 2001, 66, 5124 .

(6) (a) Enders, D.; Breuer, K.; Teles, J. H. Helv. Chim. Acta. 1996, 79, 1217. (a) Enders, D.; Breuer, K.; Raabe, G.; Runsink, J.; Teles, J. H.; Melder, J. -P.; Ebel, K.; Brode, S. Angew. Chem. Int. Ed. 1995, 34, 1021. (b) Teles, J. H.; Melder, J.-P.; Ebel, K.; Schneider, R.; Gehrer, E.; Harder, W.; Brode, S.; Enders, D.; Breuer, K.; Raabe, G. Helv. Chim. Acta 1996, 79, 61.

(7) For selected examples of thiazolium precatalyst mediated asymmetric BC reactions see: (a) Sheehan, J.; Hunnemann, D. H. J. Am. Chem. Soc. 1966, 88, 3666. (b) Sheehan, J.; Hara, T. J. Org. Chem. 1974, 39, 1196. (c) Dvorak, C. A.; Rawal, V. H. Tetrahedron Lett. 1998 , 39, 2925. (d) Takagi, W.; Tamura, Y.; Yano, Y. Bull. Chem. Soc. Jpn. 1980, 53, 478. (e) Marti, J.; Castells, J.; López-Calahora, F. Tetrahedron Lett. 1993, 34, 521. (f) Tachibana, Y.; Kihara, N.; Takata, T. J. Am. Chem. Soc. 2004, 126, 3438. (g) Knight, R. L.; Leeper, F. J. Tetrahedron Lett. 1997, 38, 3611. (h) Gerhard, A. U.; Leeper, F. J. Tetrahedron Lett. 1997, 38, 3615. (i) Knight, R. L.; Leeper, F. J. J. Chem. Soc., Perkin
Trans. 1, 1998, 1891. (j) Pesch, J.; Harms, K.; Bach, T. Eur. J. Org. Chem. 2004, 2025. (i) Mennen, S. M.; Gipson, J. D.; Kim, Y. R.; Miller, S. J. J. Am. Chem. Soc. 2005, 127, 1654.

(8) For selected examples of triazolium ion-mediated asymmetric BC reactions see: (a) Enders, D.; Breuer, K.; Teles, J. H. Helv. Chim. Acta. 1996, 79, 1217. (b) Knight, R. L.; Leeper, F. J. J. Chem. Soc., Perkin Trans. 1 1998, 1891. (b) Enders, D.; Kallfass, U. Angew. Chem. Int. Ed. 2002, 41, 1743. (c) Enders, D.; Han, J. Tetrahedron: Asymmetry 2008, 19, 1367. (d) Ma, Y.; Wei, S.; Wu, J.; Yang, F.; Liu, B.; Lan, J.; Yang, S.; You, J. Adv. Synth. Catal. 2008, 350, 2645. (e) O'Toole, S. E.; Connon, S. J. Org. Biomol. Chem. 2009, 7, 3584. (f) Baragwanath, L.; Rose, C. A.; Zeitler, K.; Connon, S. J. J. Org. Chem. 2009, 74, 9214. (g) Brand, J. P.; Osuna Siles J. -I.; Waser, J. Synlett 2010, 881.

(9) Ide, W. S.; Buck, J. S. Org. React. 1948, 4, 269.

(10) (a) Stetter, H.; Dämbkes, G. Synthesis 1977, 403. (b) Stetter, H.; Dämbkes, G. Synthesis, 1980, 309.

(11) Miller et al. reported one example of a crossed AC reaction using $o$-tolualdehyde and hexanal mediated by a triazolium ion precatalyst (stoichiometric loadings). The yield of the isolated product was $16 \%$.

(12) Intramolecular enantioselective AC reactions between aldehydes and ketones are known. For representative examples, see: (a) Enders, D.; Niemeier, O.; Balensiefer, T. Angew. Chem., Int. Ed. 2006, 45, 1463. (b) Takikawa, H.; Hachisu, Y.; Bode, J. W.; Suzuki, K. Angew. Chem., Int.Ed. 2006, 45, 3492. (c) Enders, D.; Niemeier, O.; Raabe, G. Synlett 2006, 2431. (d) Li, Y.; Feng, Z.; You, S.-L. Chem. Commun. 2008, 2263. (e) Ema, T.; Oue, Y; Akihara, K.; Miyazaki, Y.; Sakai, T. Org. Lett. 2009, 11, 4866. (f) For a recent example in the context of a multicatalytic cascade sequence, see: Lathrop, S. P.; Rovis, T. J. Am. Chem. Soc. 2009, 131, 13628.

(13) Enders, D.; Henseler, A. Adv. Synth. Catal. 2009, 351, 1749.

(14) For a recent report detailing asymmetric variants of this process see: Enders, D.; Grossmann, A.; Fronert, J.; Raabe, G. Chem. Commun. 2010, 46, 6282.

(15) For an extension of this methodology to include ketimine substrates see: Enders, D.; Henseler, Lowins, S. Synthesis 2009, 4125.

(16) a) Kuriakose, S.; Rajasekharan Pillai, V. N. Eur. Polym. J. 1994, 30, 881. (b) Kuriakose, S; Rajasekharan Pillai, V. N. Angew. Makromol. Chem. 1994, 221, 53. (c) Kuriakose, S; Rajasekharan Pillai, V. N. Polymer, 1994, 35, 1339. (d) Linghu, X.; Johnson, J. S. Angew. Chem., Int. Ed. 2003, 42, 2534. (e) Linghu, X.; Potnick, J. R.; Johnson, J. S. J. Am. Chem. Soc. 2004, 126, 3070. (f) Bausch, C. C.; Johnson, J. S. J. Org. Chem. 2004, 69, 4283. (g) Linghu, X.; Bausch, C. C; Johnson, J. S. J. Am. Chem. Soc. 2005, 127, 1833. (h) Tarr, J. C.; Johnson, J. S. Org. Lett. 2009, 11, 3870. (i) Demir, A. S.; Esiringü, I.; Göllü, M.; Reis, Ö. J. Org. Chem. 2009, 74, 2197. (j) Demir, A. S.; Reis, B.; Reis, Ö.; Eymür, S.; Göllü, M.; Tural, S.; Saglam, G. J. Org. Chem. 2007, 72, 7439. (k) Demir, A. S.; Reis, Ö.; Esiringü, I.; Reis, B.; Baris, S. Tetrahedron 2007, 63, 160. (l) Demir, A. S.; Reis, Ö.; Ciğdem, C.; Esiringü, I.; Eymur, S. J. Org. Chem. 2005, 70, 10584. (m) Bausch, C. C.; Johnson, J. S. Adv. Synth. Catal. 2005, 347, 1207. (n) Mathies, A. K.; Mattson, A. E.; Scheidt, K. A. Synlett 2009, 377. (o) Mattson, A. E.; Zuhl, A. M.; Reynolds, T. E.; Scheidt, K. A. J. Am. Chem. Soc. 2006, 128, 4932. (p) Mattson, A. E.; Scheidt, K. A. J. Am. Chem. Soc. 2007, 129, 4508 . 
(17) a) Lehwald, P.; Richter, M.; Röhr, C.; Liu, H. -W.; Müller, M. Angew. Chem. Int. Ed. 2010, 49, 2389. (b) Müller, M.; Gocke, D.; Pohl, M. FEBS Journal, 2009, 276, 2894. (c) Gocke, D.; Nguyen, C. L.; Pohl, M.; Stillger, T.; Walter, L.; Müller, M. . Adv. Synth. Catal. 2007, 349, 1425. (d) Demir, A. S.; Şeşengolu, Ö.; Dünkelmann, P.; Müller, M. Org. Lett. 2003, 5, 2047. (e) Dünkelmann, P.; Kolter-Jung, D.; Nitsche, A.; Demir, A. S.; Siegert, P.; Linden, B.; Baumann, M.; Pohl, M.; Müller, M. J. Am. Chem. Soc. 2002, 124, 12084. (f) Demir, A. S.; Şeşengolu, Ö.; Eren, E.; Hosrik, B.; Pohl, M.; Janzen, E.; Kolter, D.; Feldmann, R.; Dünkelmann, P.; Müller, M. Adv. Synth. Catal. 2002, 344, 96. (g) Pohl, M.; Lingen, B.; Müller, M. Chem. Eur. J. 2002, 8, 5288. (h) Demir, A. S.; Pohl, M.; Janzen, E.; Müller, M. J. Chem. Soc,. Perkin Trans. 1, 2001, 633 .

(18) O'Toole, S. E.; Rose, C. A.; Gundala, S.; Zeitler, K.; Connon, S. J. J. Org. Chem. 2010, DOI: 10.1021/jo101791w.

(19) We have previously reported that thiazolium ions can mediate the oxidation of aldehydes in the presence of a stoichiometric oxidant. Triazolium ions were poor catalysts for this process. In recalcitrant reactions involving 18 and protic solvent it is possible that the presence of adventitious oxygen may be responsible for low product yields: Noonan, C.; Baragwanath, L.; Connon, S. J. Tetrahedron Lett. 2008, 49, 4003.

(20) Vora, H. U.; Lathrop, S. P.; Reynolds, N. T.; Kerr, M. T.; Read de Alaniz, J; Rovis, T. Org. Synth. 2010, 87, 350.

(21) In order to reproduce the conditions on a smaller scale we found a tube shaped flask better suited to handle smaller amounts of solvent (cf. high concentration of the reactions performed by Stetter (ca. $3 \mathrm{M})$ ).

(22) (a) Stetter, H.; Rämsch, R. Y.; Kuhlmann, H. Synthesis 1976, 733. (b) Cumper, C. W. N.; Thurston, A. P. J. Chem. Soc., Perkin Trans 2, 1972, 106. 


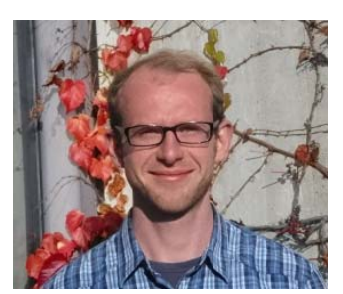

Christopher Rose was born in 1981 in Forchheim, Germany. He studied chemistry at the University of Regensburg and obtained his Diploma degree in 2006. Currently he is completing his Ph.D. under the supervision of Dr. Kirsten Zeitler. His research focuses on the development of novel carbene catalysed $\mathrm{C}-\mathrm{C}$ and $\mathrm{C}-\mathrm{O}$ bond forming reactions.

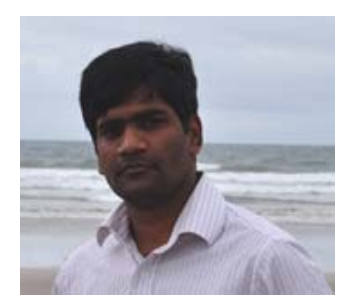

Sivaji Gundala was born in 1986 in Nandigama, India. Sivaji obtained his B.Sc from Acharya Nagarjuna University in 2006 and his M.Sc in chemistry from University of Hyderabad in 2008. After this he worked as a student researcher in Glaxo Smith Kline, Cork, Ireland, before starting his $\mathrm{PhD}$ at Trinity College Dublin in 2009(October), working under the supervision of Prof.Stephen Connon. His interests focus on carbene catalysis and novel asymmetric organocatalytic processes.

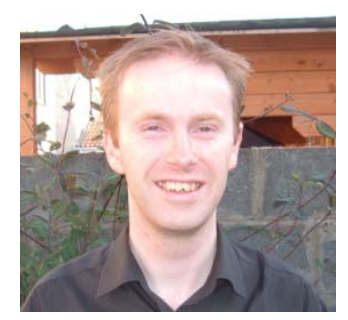

Stephen Connon was born in 1976 and received his $\mathrm{PhD}$ from University College Dublin under the supervision of Prof. A. F. Hegarty in 2000. After being awarded an Alexander von Humboldt fellowship he spent two years at the Technische Universität Berlin with Prof. S. Blechert, studying the design of new olefin metathesis catalysis. In 2003 he was appointed to the staff of Trinity College where he is currently Professor of Synthetic Chemistry. His research interests include organocatalysis, the discovery and development of novel synthetic methodology and the design of new anti-cancer and anti-bacterial agents.

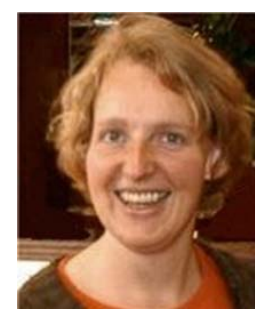

Kirsten Zeitler was born in Augsburg (Germany) and received her PhD from the LudwigMaximilians Universität München under the guidance of Prof. W. Steglich in 2001. As a fellow of the German Academic Exchange Service (DAAD) she joined the group of Prof. G. A. Molander at the University of Pennsylvania for postdoctoral studies. Being awarded with a Liebig fellowship of the Fonds der Chemischen Industrie she started her independent career as a junior research group leader at of the University of Regensburg in summer 2004. The research interests of her group include organocatalysis as well as photocatalysis and the development of new synthetic methodology applying biomimetic principles.

Table of contents graphic

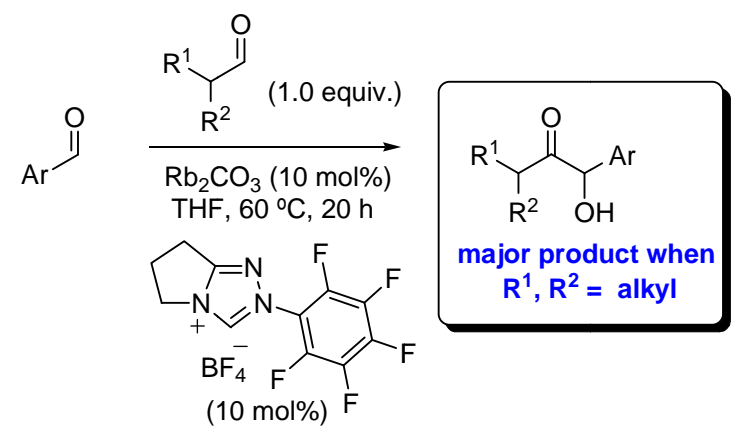

\section{Short title: Crossed Acyloin Condensations}


